\title{
Epigean freshwater Gammaridae (Crustacea, Amphipoda) from La Gomera (Canary Islands)
}

\author{
Gabriele Beyer* \& Jan H. Stock** \\ * c/o Institut für Landwirtschaftliche Zoologie und Bienenkunde, Rheinische Friedrich-Wilhelms- \\ Universität, Melbweg 42, 53127 Bonn, Germany; ** c/o Institute of Systematics and Population \\ Biology, University of Amsterdam, P.O. Box 94766, 1090 GT Amsterdam, The Netherlands
}

Keywords: La Gomera, Canary Islands, freshwater Amphipoda, taxonomy, Rhipidogammarus, Chaetogammarus, new species

\begin{abstract}
Description of two new species of freshwater amphipods from La Gomera (Canary Islands), both found in the higher parts of the island: Chaetogammarus chaetocerus $\mathrm{n}$. sp. and Rhipidogammarus gomeranus n. sp. Both species have distinct AfroIberian relationships.
\end{abstract}

\section{Resumen}

Descripción de dos nuevas especies de Anfípodos limnícolos de la zona elevada en La Gomera (Islas Canarias): Chaetogammarus chaetocerus n. sp. y Rhipidogammarus gomeranus n. sp. Dichas especies estan estrechamente relacionadas con formas afro-ibericas.

\section{Introduction}

Two species of hypogean Amphipoda have been recorded from La Gomera, a small island in the western Canary archipelago (see Stock, 1988a and Stock \& Vonk, 1990), and a probably epigean species was recorded without any locality or habitat data (Karaman, 1991). The present paper, based on the fieldwork of one of the authors (G.B.), describes two species of epigean amphipods, both new, found in freshwater streams of the island.

\section{Material and methods}

The specimens were hand-sampled in springs and small streams of the island. Of the 49 stations (and many substations) sampled, the following yielded aquatic Amphipoda (a more detailed account of these stations can be found in Beyer, 1993):

Sta. 11c. Left spring brook of the El Cedro system, in a rockpool, UTM coordinates BS $281 \times{ }^{31} 12,980 \mathrm{~m}$ above sea level, 14 March 1991 , water temp. $11.5-13.5^{\circ} \mathrm{C}$, pH 7.4-7.5, $\mathrm{Ca}^{2+}$ $12-16 \mathrm{mg} / \mathrm{l}, \mathrm{Cl}-34 \mathrm{mg} / \mathrm{l}$.

Sta. 13a-b. Left spring brook of the El Cedro system, in a rift, UTM BS $281 \times{ }^{31} 11,1050 \mathrm{~m}$ above sea level, 9-14 April 1991, water temp. $13.4^{\circ} \mathrm{C}, \mathrm{pH} 7.4, \mathrm{Ca}^{2}+12 \mathrm{mg} /, \mathrm{Cl}^{-}$not determined.

Sta. 16b. Left spring brook of the El Cedro system, UTM BS $282 \times{ }^{31} 11,1130 \mathrm{~m}$ above sea level, water runs over a short steep rock slope, 19 May 1991. No physicochemical data.

Sta. 20a-d. Pajarito (the highest spring of the El Cedro system). UTM BS $280 \times{ }^{31} 11,1200-1210 \mathrm{~m}$ above sea level, various dates in spring and summer of 1991 and 1992, water temp. 10.0-12.2 ${ }^{\circ} \mathrm{C}, \mathrm{pH} 6.4-6.5 ; \mathrm{Ca}^{2}+8-10 \mathrm{mg} / \mathrm{l}, \mathrm{Cl}-32 \mathrm{mg} / 1$.

Sta. 25a-b. Las Mesetas, stream in Ocotea forest, UTM BS $275 \times{ }^{31} 16,850 \mathrm{~m}$ above sea level, $17 \mathrm{July} 1992$, water temp. $15.1^{\circ} \mathrm{C}, \mathrm{pH} 7.4, \mathrm{Ca}^{2}+18 \mathrm{mg} / \mathrm{l}, \mathrm{Cl}^{-} 110 \mathrm{mg} / \mathrm{l}$.

Sta. 36a-b. Spring, Montaña de la Caldera, UTM BS $275 \times$ $3120,790 \mathrm{~m}$ above sea level, thin layer of running water on rock, 6 July 1992, no physicochemical data.

Sta. 39a-c. Fuente Erque, on wet rockwall in rift, in mud below the rock and in aquaduct, UTM BS $278 \times{ }^{31} 10,980 \mathrm{~m}$ above sea level, $7 \& 10$ July 1992 , water temp. $16.0^{\circ} \mathrm{C}, \mathrm{pH} 7.6$, $\mathrm{Ca}^{2}+8 \mathrm{mg} / \mathrm{l}, \mathrm{Cl}-22 \mathrm{mg} / \mathrm{l}$.

Of the above stations, nrs. 11 through 20 , all belonging to the El Cedro stream system within the Laurisilva forest of the Garajonay National park, contained a new species of Chaetogammarus; stations 25 through 39, in the north-west and south-west of the island, yielded a new species of Rhipidogammarus.

The type material of both new species has been deposited in the Zoölogisch Museum, Amsterdam (ZMA). Part of the samples (not the types) have been retained by the first author. 


\section{Taxonomic part}

Family Gammaridae

Genus Chaetogammarus Martynov, 1924

\section{Chaetogammarus chaetocerus n. sp.}

(Figs. 1-3)

Material. - All from La Gomera (Canary Islands): Sta. 13a-b, 1 o (holotype), 1 ovigerous $\$$ (allotype), 48 paratypes (ZMA Amph. 200.788). Sta. 11c, 20 specimens (ZMA Amph. 100.789). Sta. 16b, 4 specimens. Sta. 20a-d, 37 specimens (ZMA Amph. 200.790). Ovigerous females present in all samples.

Description. - Body length of male up to $8 \mathrm{~mm}$, ovigerous females 6-7 mm. Live colour dark brown; eye (Fig. 1a) well-pigmented, ovate, much less than twice as long as wide. Lateral head lobe truncate (Fig. 1a). Pereionites and pleonites without dorsal armature; urosomites with spines and a few short setules; number of elements on urosomites variable: 1 or 2 middorsal spines, 0 or 1 dorsolateral spines (Fig. 1c).

Adult male: Antenna 1 (Fig. 1e): peduncle segment 1 with 3 ventral groups of short setae; segments 2 and 3 each almost 3 times as long as wide, with 6 and 4 groups, respectively, of setae on ventral margin, increasing in length towards distal part of segment (twice as long as segment diameter); flagellum 22-segmented, proximal segments with longer setae than distal segments; one aesthetasc present on each of segments 4 through 19, club-shaped, short (ca. 20\% of length of corresponding segment); accessory flagellum rather long, 4-segmented.

Antenna 2 (Fig. 1f): gland cone strongly tapering, pointed; peduncle segments 4 and 5 , and 9-segmented flagellum with "brush" of numerous transverse rows of very long setae; no calceoli.

Lacinia mobilis of left mandible 4-dentate; of right mandible trifid, finely toothed; palp (Fig. 1h) segment 1 unarmed; segment 2 with numerous long setae along ventral margin; segment 3 with 2 groups of 4 and 3 A-setae, 2 or 3 B-setae, 6 C-setae, ca. 20 D-setae of somewhat irregular length, and 5 E-setae.

Maxilla 1: left palp narrower than right one; dis- tal armature of second palp segment of 10 slender spines +4 setae (left), or 5 spine-teeth +1 spine +1 seta (right). Remaining mouthparts without peculiarities.

Gnathopod 1 (Fig. 2a): coxal plate with some small setules on anteroventral and posteroventral corners, and row of some 10 minute submarginal ventral setules; carpus elongate-triangular; propodus with 3 pointed palmar angle spines and 1 pointed, so-called mid-palmar spine (which in reality is implanted rather close to palmar angle); palma oblique, long, slightly concave.

Gnathopod 2 (Fig. 2b) of about same size as gnathopod 1; coxal plate narrower than in gnathopod 1; coxal gill stalked, ovate, almost reaching to distal end of basis; carpus trapezoidal; carpus and propodus strongly setose; propodus elongate-oval, palma short, concave; palmar angle with 4 pointed spines, so-called mid-palmar spine pointed, placed close to palmar angle.

Pereiopod 3 (Fig. 2c) longer and more strongly setose than pereiopod 4; coxal plate narrow, with short submarginal setules along ventral margin; setae on merus, carpus, and propodus long.

Pereiopod 4 (Fig. 2d): coxal plate wide, with shallow posterior emargination, ventral margin naked; setae on merus long, on carpus and propodus short.

Pereiopod 5 (Fig. 3b): coxal plate bilobate; coxal gill almost as large as that of pereiopods 3 and 4; basis subrectangular, posteroventral corner produced, unarmed, posterior margin with ca. 14 minute serrations, each with a minute setule; merus and carpus spinous.

Pereiopod 6 (Fig. 3c) hardly longer than pereiopod 5; coxal plate distinctly bilobate, coxal gill smaller than that of pereiopod 5; basis tapering, posteroventral corner not produced, armed with 1 spine, posterior margin with ca. 12 minute setules; distal segments almost without setae.

Pereiopod 7 (Fig. 3d) about as long as pereiopod 6; coxal plate slightly bilobate, small; no coxal gill; basis strongly tapering, posteroventral corner not produced, unarmed; posterior margin with ca. 16 setules and a submarginal spine; long segments similar to those of pereiopod 6.

Epimeral plate 1 with rounded posteroventral 

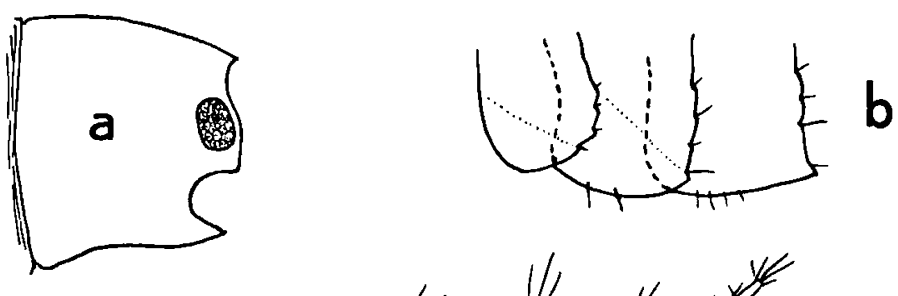

e
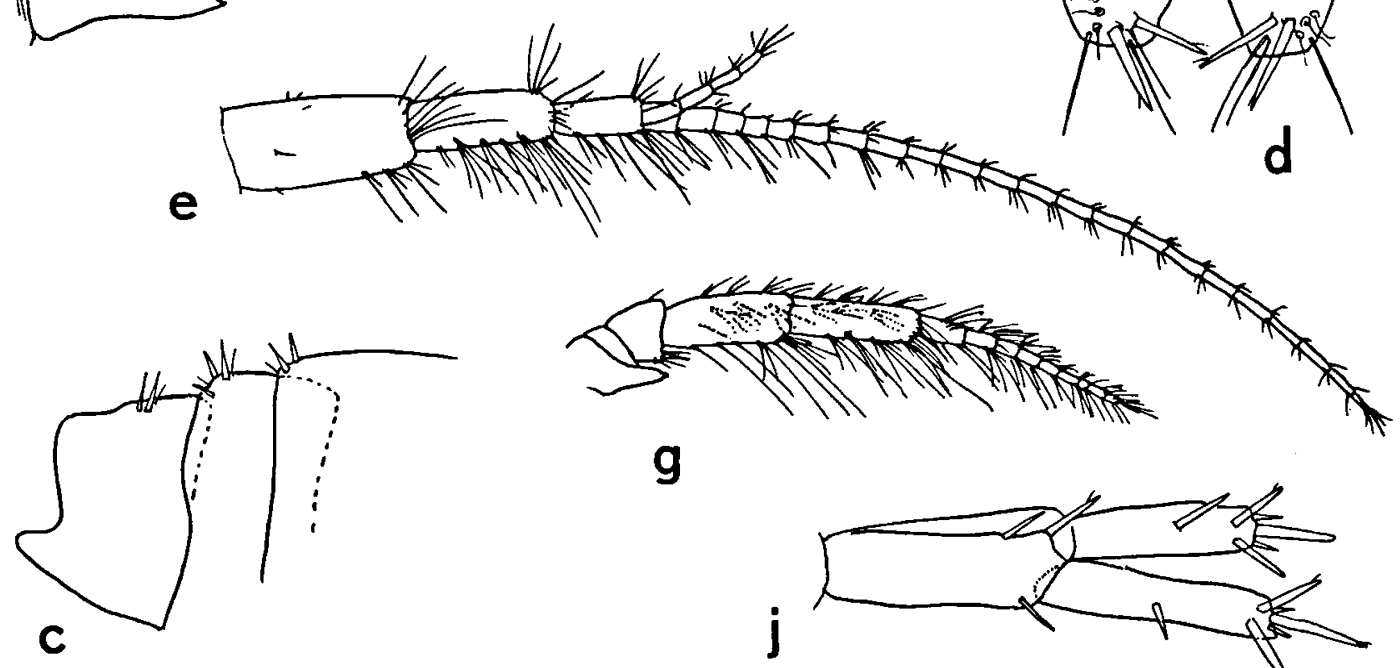

g
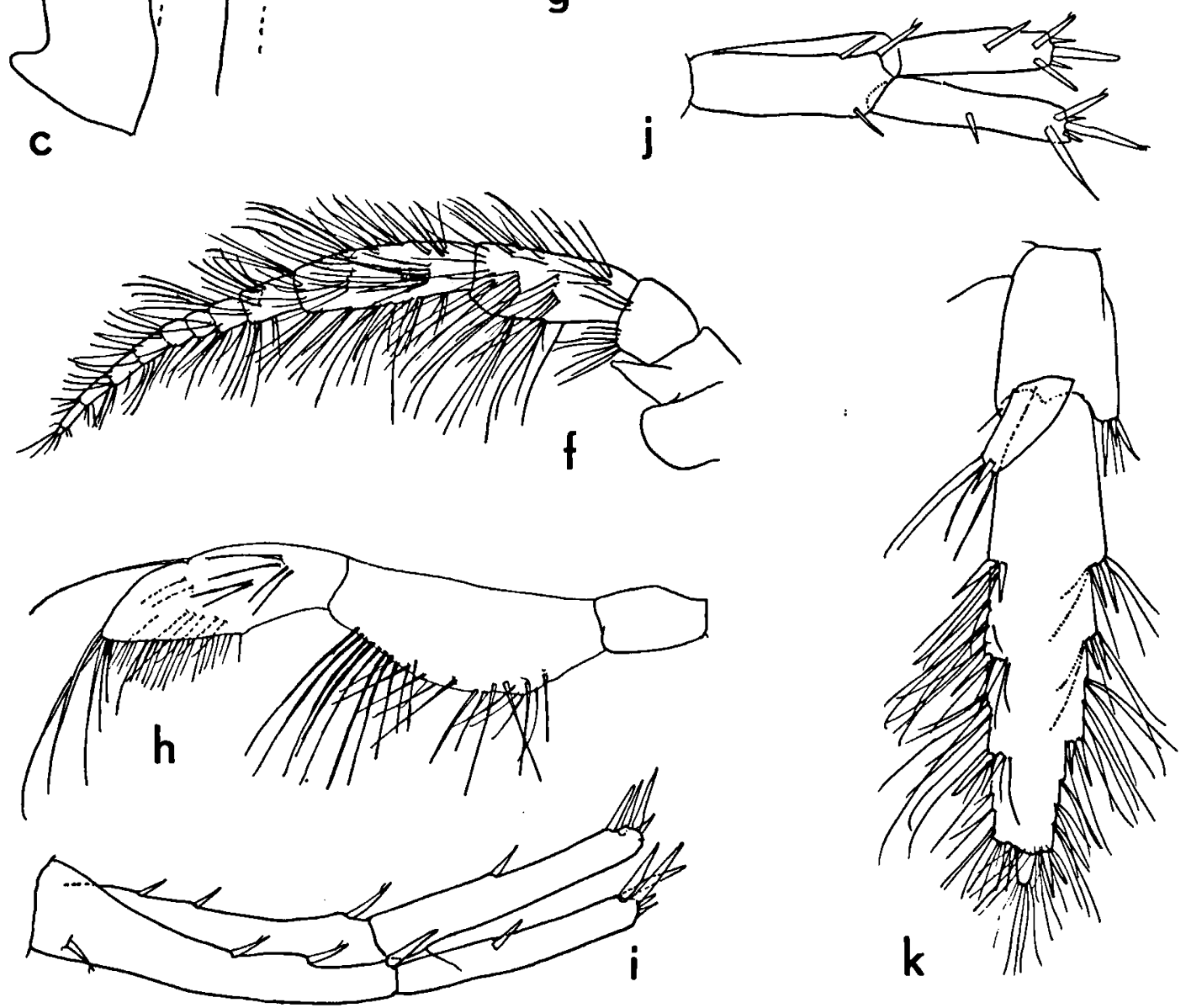

Fig. 1. Chaetogammarus chaetocerus n. sp. (g, ovigerous $\$, 7 \mathrm{~mm}$, all others $\sigma, 8 \mathrm{~mm}$, all from sta. 20d): a, head, from the right (scale 5); b, epimeral plates from the left (5); c, contour of urosome, from the right (1); d, telson (4); e, antenna 1 (2); f, antenna 2 (2); g, antenna 2 (2); h, mandible palp (4); i, uropod 1 (1); j, uropod 2 (1); k, uropod 3, plumosity of all exopodal setae omitted (1). Scales on Fig. 3. 


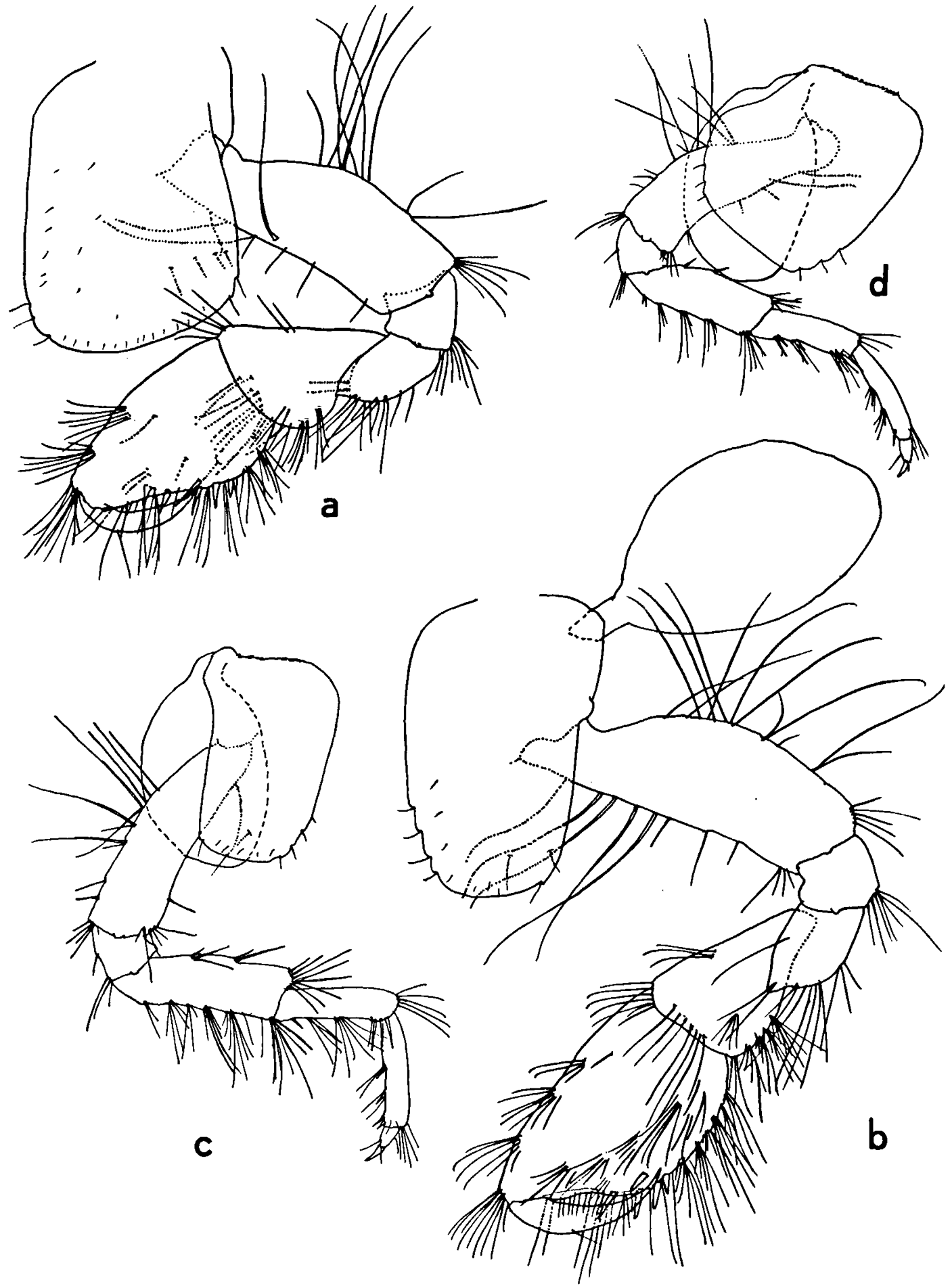

Fig. 2. Chaetogammarus chaetocerus n. sp. (o, $8 \mathrm{~mm}$, from sta. 20d): a, gnathopod 1 (scale 1); b, gnathopod 2 (1); c, pereiopod 3 (2); d, pereiopod 4 (2). Scales on Fig. 3. 


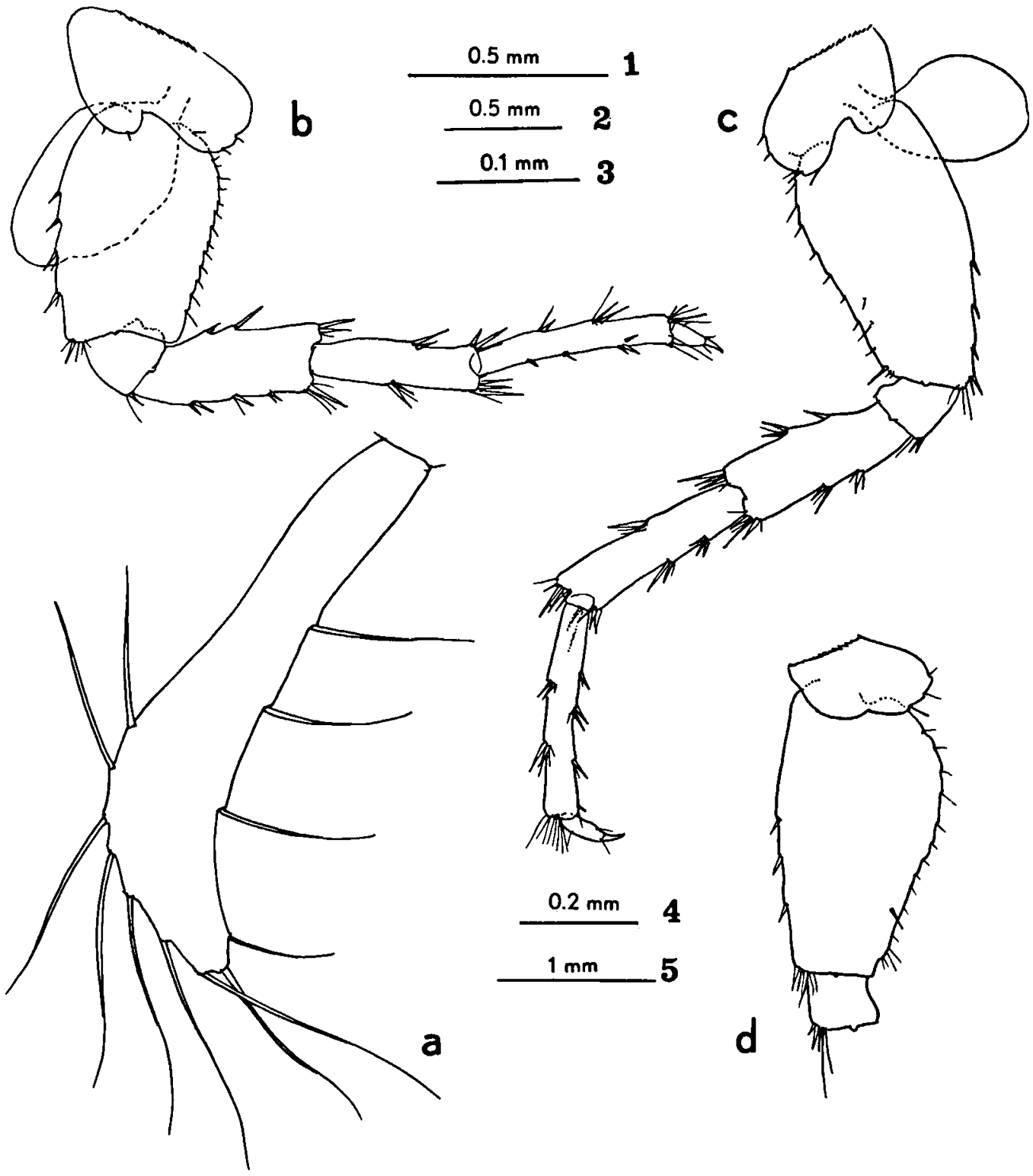

Fig. 3. Chaetogammarus chaetocerus n. sp. (a, ovigerous $\$, 7 \mathrm{~mm}$; b-d, ơ, $8 \mathrm{~mm}$, all from sta. 20d): a, oostegite of pereiopod 3 (scale 4); b, pereiopod 5 (2); c, pereiopod 6 (2); d, proximal segments of pereiopod 7 (2).

corner, ventral margin unarmed; plate 2 with rectangular posteroventral corner, ventral margin with 2 setules; plate 3 with slightly pointed posteroventral corner, ventral margin with 4 setules; posterior margin of all plates crenulate, with several setules (Fig. 1b).

Uropod 1 (Fig. 1i) with proximoventral peduncular spine; exopodite slightly shorter than endopo- dite; dorsal armature of both rami somewhat variable (with or without middorsal spine).

Uropod 2 (Fig. 1j): exopodite slightly shorter than endopodite; 0 or 1 middorsal spine on each ramus.

Uropod 3 parviramous (Fig. 1k): exopodite 2segmented, distal segment very small; lateral, medial, and distal margins of first exopodal segment 


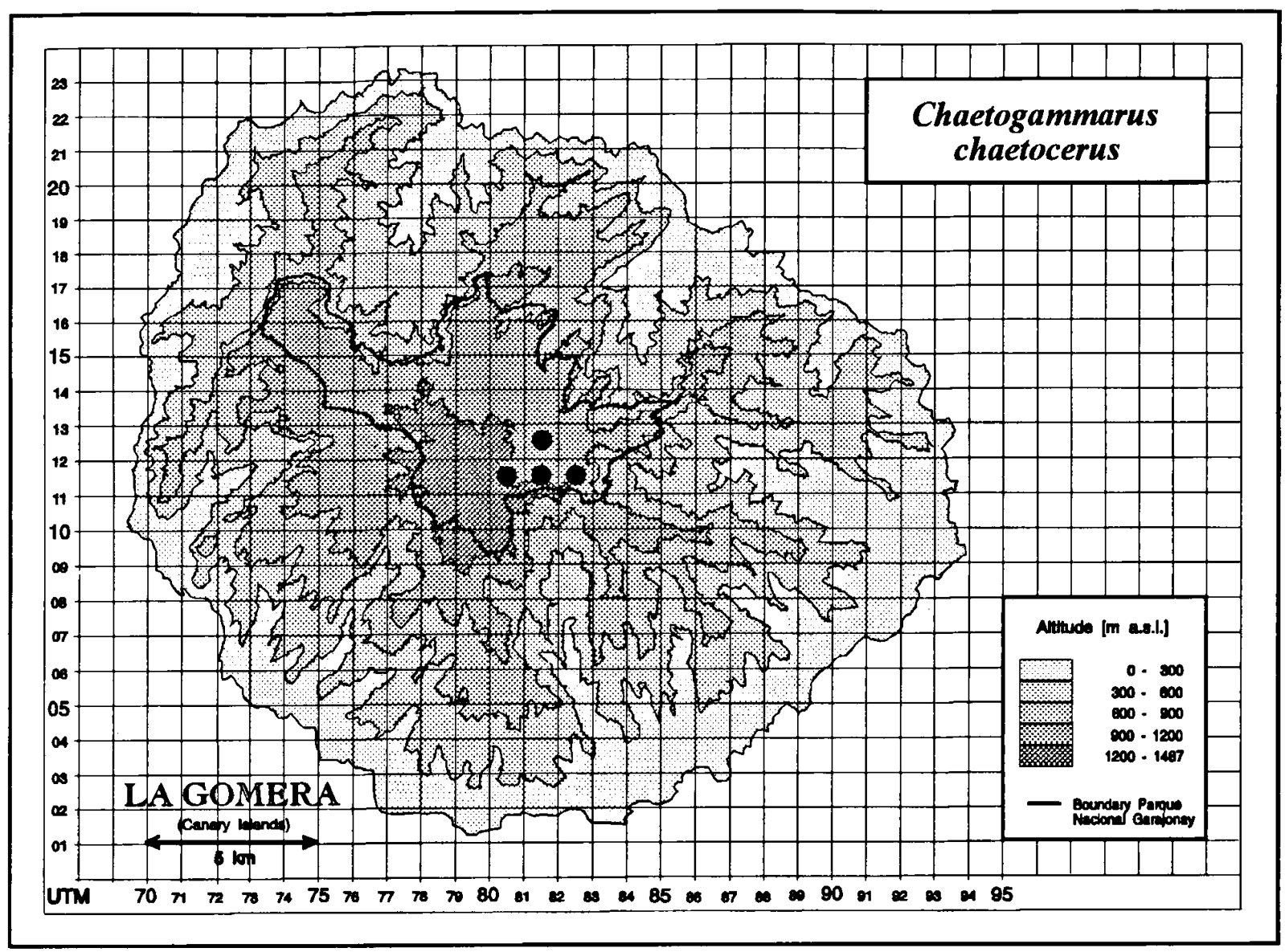

Fig. 4. Distribution of Chaetogammarus chaetocerus n. sp. in La Gomera (a.s.l. = above sea level).

with very long, partly plumose, setae; endopodite elongate-oval, with 1 distal spine and some very long distal setae.

Telson (Fig. 1d) with 2 distal spines, 3 distal setae (slightly overreaching the spines) and three subterminal sensory setules; lateral margin unarmed, but middorsal spine sometimes present.

Female: Up to 10 small eggs. Antenna 2 (Fig. 1g) with less dense setal "brush" on flagellum than in male. Gnathopods 1 and 2 smaller; propodus of gnathopod 2 slightly larger than that of gnathopod 1. Oostegites (Fig. 3a) narrow. Setae on outer margin of exopodite of uropod 3 shorter than in male.

Etymology. - The specific name, chaetocerus, is a latinization of the combination of the Greek words $\chi \alpha i \tau \eta(=$ hair) and $\kappa \varepsilon \dot{\varepsilon} \alpha \varsigma$ (= horn), alluding to the strongly setose first and in particular second antennae of the new species.

Ecology and distribution. - Up to now Chaetogammarus chaetocerus has been found exclusively in the upper reaches of the El Cedro stream system (Fig. 4) lying in the wooded Laurisilva zone of La Gomera, where it is limited to higher altitudes (980-1210 m above sea level). Apparently, it shows no particular demands as to microhabitat, since it was found both in the Pajarito spring basin and in the connecting upper reaches of the stream. The animals were found crawling in a thin layer of water on steep rocks, but also in the deeper water of a rock pool. No clear substrate preference was noted, except that the species was more often found on cobbles and rocks. The animals are not markedly photophobic. The population was of medium size. 
Discussion. - The only species of Chaetogammarus known from the Canary Islands is Ch. olivii $(\mathrm{H}$. Milne Edwards, 1830) (see Stock, in press), which is easily distinguished from $C h$. chaetocerus by its large, elongate eye, strongly shortened 5 th pereiopod, and a less strong setosity of the 2 nd antenna, and last but not least by a quite different habitat, viz. on cobble beaches with temporary freshwater influences of small streams at low tide, and immersion by seawater at high tide.

Often, the genera Echinogammarus and Chaetogammarus are considered synonymous (see e.g. Karaman, 1977; Barnard \& Barnard, 1983; Pinkster \& Platvoet, 1990). Cladistics indicate that the berilloni-group is a more isolated clade (Stock, in press). For this reason, the generic name Echinogammarus is used here only for the species belonging to the berilloni-group (to which the type-species of Echinogammarus, E. berilloni, belongs), whereas the name Chaetogammarus is applied to most of the remaining species.

The present species from La Gomera does not belong to the berilloni-group, but to the simoni-group (as defined by Pinkster \& Stock, 1972), and is consequently classified with Chaetogammarus.

The simoni-group comprises the following species only: Ch. simoni (Chevreux, 1894), Ch. tacapensis (Chevreux \& Gauthier, 1924), Ch. lusitanus (Schellenberg, 1943), Ch. lochites (Margalef, 1958), Ch. obtusidens (Pinkster \& Stock, 1972), Ch. valedictus (Pinkster \& Platvoet, 1990), and perhaps the more remotely related species $\boldsymbol{C h}$. dactylus (Karaman, 1988) and Ch. afer (Stock, 1974).

Of these, Ch. tacapensis, Ch. dactylus, and Ch. afer can be distinguished at once from $C h$. chaetocerus by having a regressed, 1- or 2-segmented accessory flagellum in the first antenna. Ch. valedictus can be distinguished from $C h$. chaetocerus by a monomerous exopodite of the third uropod (although recently doubt was cast on the taxonomic value of this character by Jaume, 1992), the presence of longish submarginal setae on coxal plates 1 to 4 , the scanty setation of antenna 1 , a more strongly pointed 3 rd epimeral plate, and the presence of long setae on merus and carpus of pereiopod 7.
Ch. obtusidens, Ch. afer; and Ch. lochites possess a vary sparse and short setation of antenna 1 and peduncle segments 4 and 5 of antenna 2 , which (in addition to other characters) distinguish these species at first sight from Ch. chaetocerus.

Ch. lusitanus has an elongate eye-shape, poorly setose antennae, and bears calceoli on the flagellum of antenna 2 of the male, and therefore cannot be confused with $C h$. chaetocerus.

The only species which resembles the animals from La Gomera more closely, in particular by the strong setosity of the second antenna, is Ch. simoni. However, Ch. simoni bears shorter setae on peduncle segments 2 and 3 of antenna 1 (about as long as the diameter of these segments in simoni, vs. twice as long in chaetocerus). Moreover these peduncle segments are strongly shortened in $\boldsymbol{C h}$. simoni, vs. elongate in Ch. chaetocerus. Additional differences reside in a more angular epimeral plate 1 (rounded in Ch. chaetocerus), strongly pointed epimeral plates 2 and 3 (weakly pointed in $C h$. chaetocerus), and the setae on the exopodite of uropod 3, which are as long as the diameter of the segment in Ch. simoni, but much longer in $C h$. chaetocerus.

\section{Genus Rhipidogammarus Stock, 1971}

\section{Rhipidogammarus gomeranus $\mathrm{n} . \mathrm{sp}$.}

Figs. 5, 6, 7a-c

Material. - All from La Gomera (Canary Islands): Sta. 36a-b, $1 \%$ (holotype), 1 ovigerous $\&$ (allotype), 133 paratypes (ZMA Amph. 200.785). Sta. 25a-b, 8 specimens (ZMA 200.786). Sta. 39a-c, 67 specimens (ZMA 200.787). Ovigerous females present in all samples.

Description. - Body length of both sexes, excluding antennae and uropods, 4-5 $\mathrm{mm}$, occasionally up to slightly over $7 \mathrm{~mm}$. In life, body light coloured. Head lobe (Fig. 5a) truncate; eye reniform, not very large, well-pigmented. Urosomites 1 and 2 dorsally armed with 1 spine +2 setules; urosomite 3 dorsally unarmed; lateral armature of urosomite 1 to 3 consisting of 1 spine +1 setule, 2 spines, and 1 spine +1 setule, respectively (Fig. 5 h). Epimeral plates 1 to 3 with rounded posteroventral corner; 

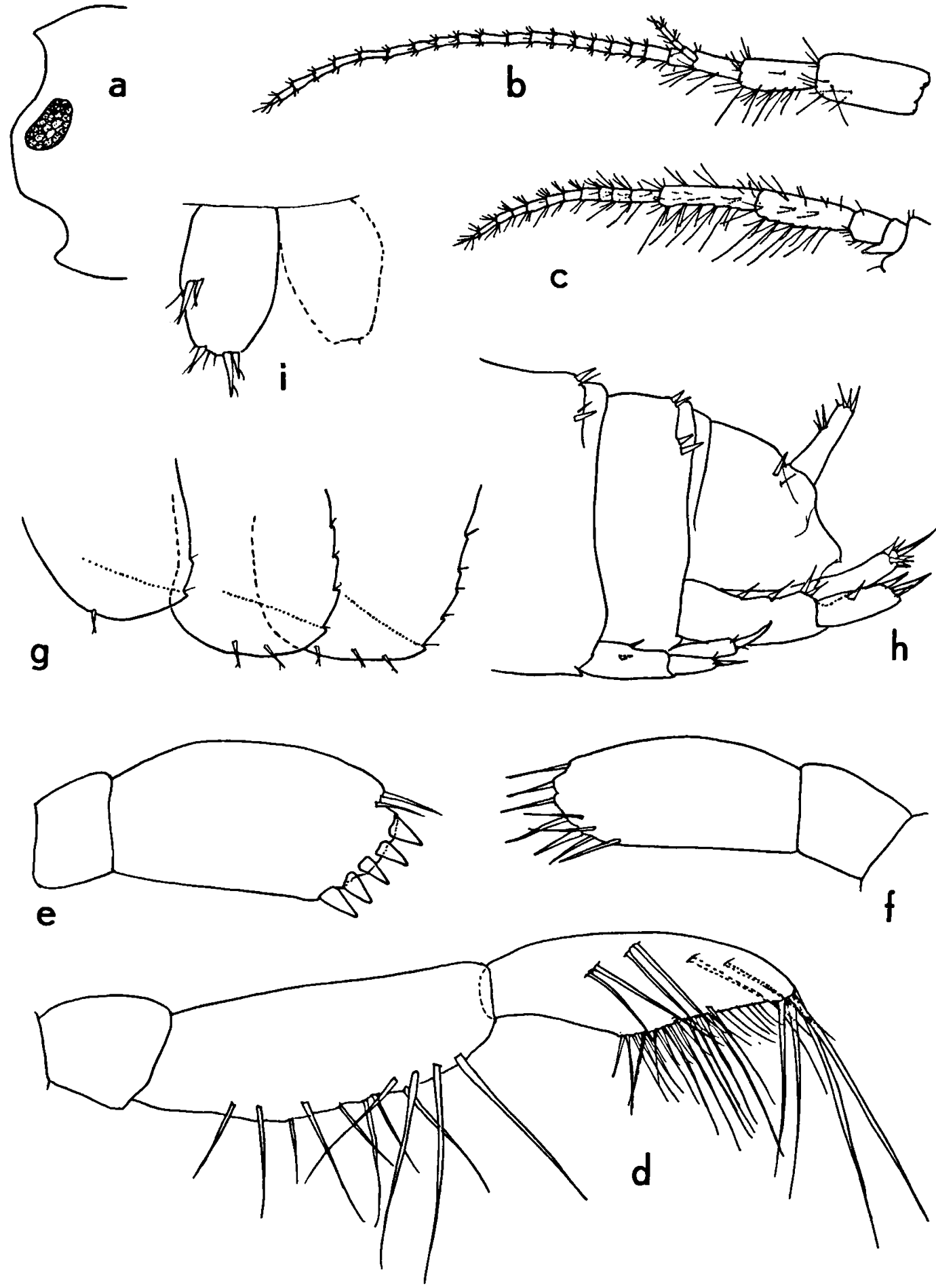

Fig. 5. Rhipidogammarus gomeranus n. sp. (ơ, $7.2 \mathrm{~mm}$, from sta. 25a-b): a, head, from the left (scale 1); b, antenna l (2); c, antenna 2 (2); d, mandible palp (3); e, palp of maxilla 1, right (3); f, palp of maxilla 1, left (3); g, epimeral plates, from the left (1); h, urosome, from the left (1); i, telson (3). Scales on Fig. 3. 

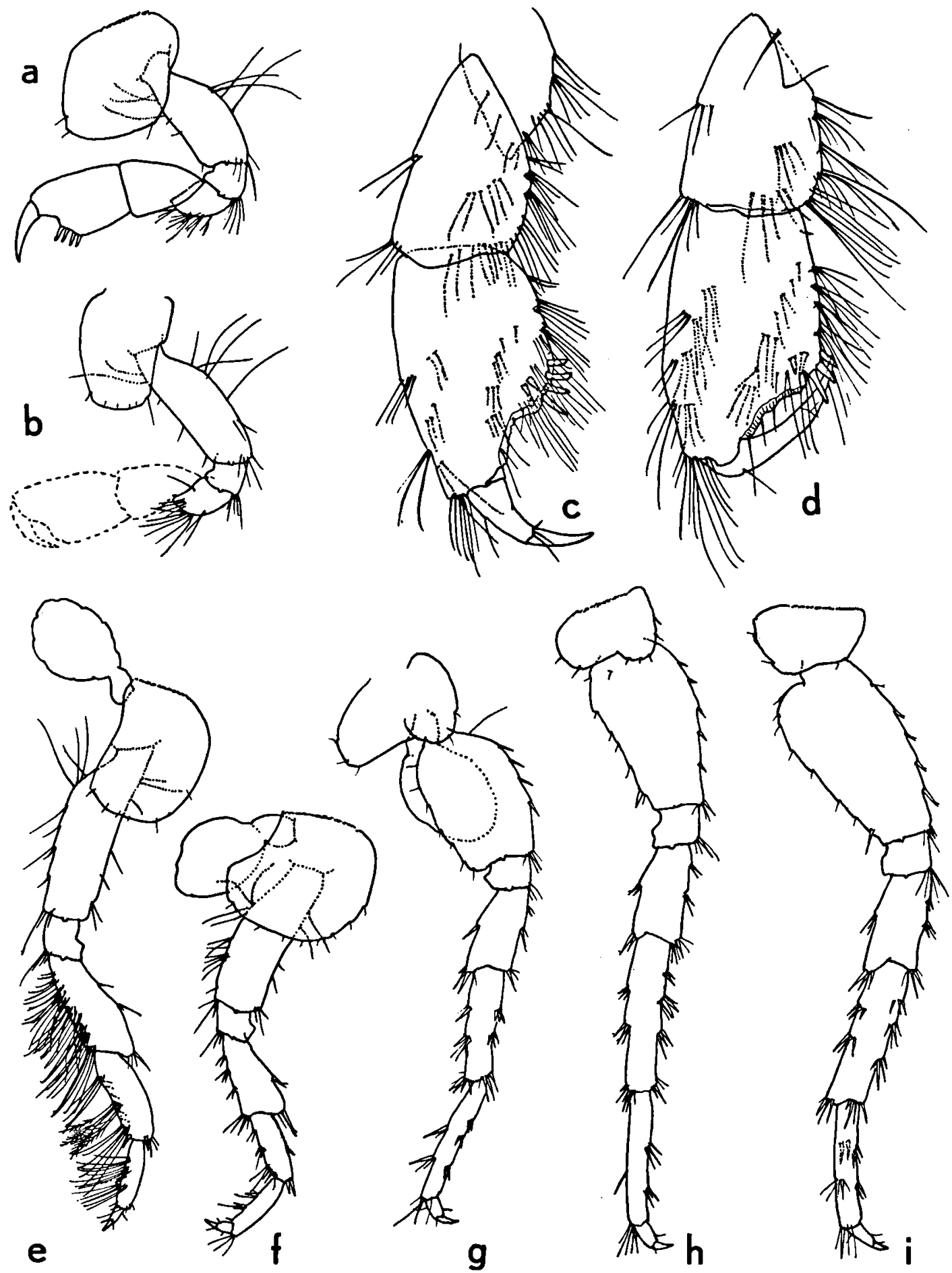

Fig. 6. Rhipidogammarus gomeranus n. sp. ( $\left(0^{\circ}, 7.2 \mathrm{~mm}\right.$, from sta. 25a-b): a, gnathopod 1 (scale 2); b, gnathopod 2 (2); c, distal segments of gnathopod 1 (4); d, distal segments of gnathopod 2 (4); e, pereiopod 3 (2); f, pereiopod 4 (2); g, pereiopod 5 (2); h, pereiopod 6 (2); i, pereiopod 7 (2). Scales on Fig. 3. 


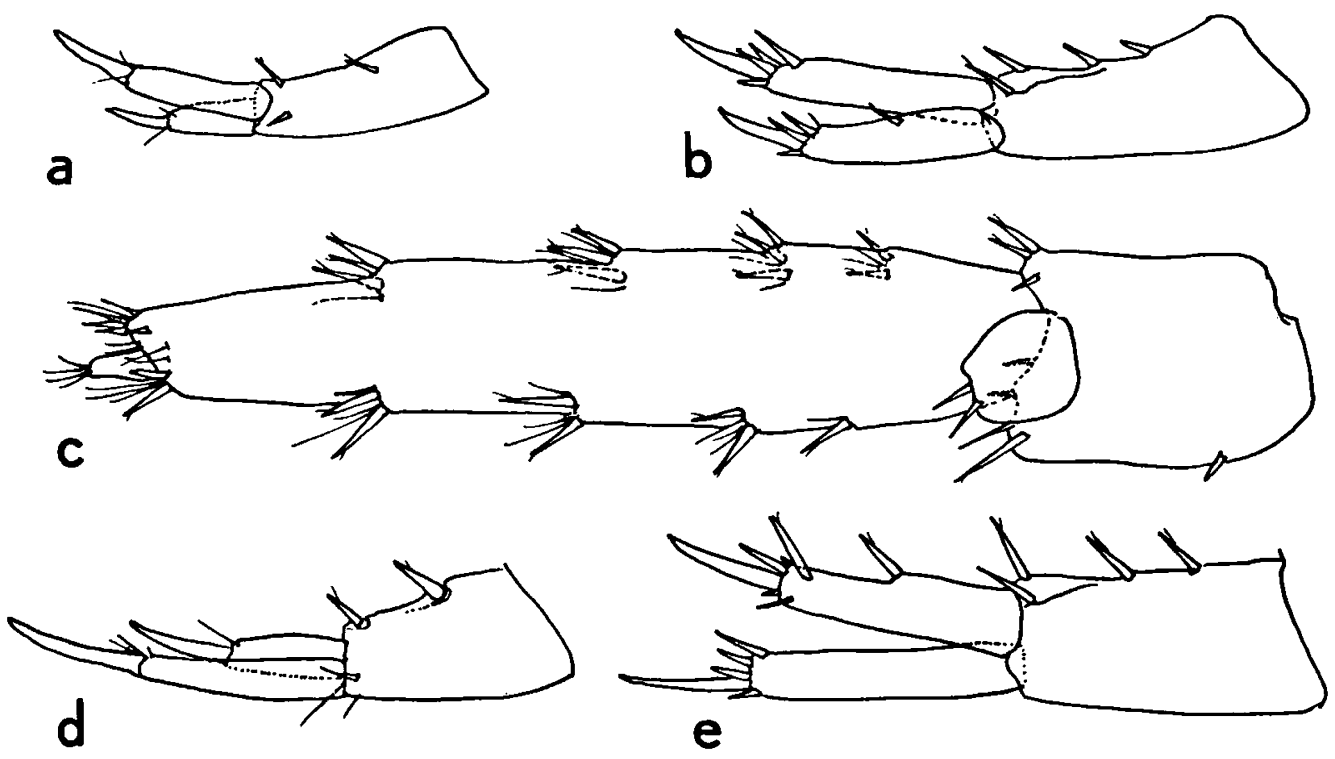

Fig. 7a-c, Rhipidogammarus gomeranus n. sp. (o, $7.2 \mathrm{~mm}$, from sta. 25a-b): a, uropod 1 (scale 4); b, uropod 2 (4); c, uropod 3 (4). d-e, Rhipidogammarus triumvir Notenboom, 1985 ( $0^{\circ}, 8 \mathrm{~mm}$, from Nijar, Almeria, Spain): d, uropod 1 (4); e, uropod 2 (4). Scales on Fig. 3.

ventral margin with 1, 2, and 3 spines, respectively; posterior margin weakly notched, with some small setules (Fig. 5g).

Adult male: Antenna 1 (Fig. 5b): peduncle segment $1>2>3$; segment 2 with 6 groups of long ventral setae (longer than diameter of segment); segment 3 with 2 groups of long ventral setae; flagellum 20-segmented, each segment armed with short setules only; one aesthetasc present on each segment from third to antepenultimate, club-shaped, about $30 \%$ of length of corresponding segment; accessory flagellum 4-segmented, reaching beyond tip of flagellum segment 2 .

Antenna 2 (Fig. 5c): gland cone tapering, pointed; peduncle segments 4 and 5 slender and elongate, each with 6 groups of very long setae, placed on serrate ventral margin; flagellum 10-segmented; no calceoli.

Upper and lower lips without peculiarities.

Mandible: Left lacinia mobilis 4-dentate: right lacinia bifid, finely toothed. Mandible palp (Fig. 5d) with elongate 2 nd and 3rd segments; distal setae of 2nd segment reaching D-setae of segment 3; segment 3 with 2 A-setae, 4 B-setae, and some 16 D-setae of uniform size, and 5 E-setae; C-setae numerous (up to 8), implanted very close to ventral margin and not restricted to the proximal part of it; since they occur intermixed with the D-setae, they suggest the existence of an irregular row of D-setae.

Maxilla 1 as in $R h$. nivariae Stock, 1988, but distal segment of right palp with 5 spine-teeth, of left palp with 9 setae (Figs. $5 e-f$ ).

Maxilla 2 and maxilliped without peculiarities.

Gnathopod 1 (Fig. 6a): coxal plate trapezoidal, free anterior and posterior corners with good-sized setule, ventral margin naked; posterior margin of basis with 4 long setae, anterior margin with small setules only; posterior margin of merus with 3 groups of setae; carpus < propodus; carpus with 4 groups, propodus with 3 groups of setae on posterior margin; propodus subovate, 4 strong marginal and 2 submarginal palmar angle spines; palmar margin strongly concave, without mid-palmar spine (Fig. 6c).

Gnathopod 2 (Fig. 6b): coxal plate slightly tapering, subrectangular; free corners with good-sized setule; carpus $<<$ propodus; carpus with 5 groups of setae on posterior margin; propodus slightly larger and more rectangular than that of gnathopod 1; posterior margin with 4 groups of setae; palma weakly concave; no mid-palmar spine; 3 long mar- 
ginal and 2 submarginal spines on palmar angle (Fig. 6d).

Pereiopod 3 (Fig. 6e) with transverse rows of long plumose setae along posterior margin of merus, carpus, and propodus. Pereiopod 4 (Fig. 6f) shorter than pereiopod 3, coxal plate slightly wider than long, with short setules along ventral margin, posterior emargination deep; anterior margin of merus with 1 or 2 spines, that of carpus with 1 spine.

Pereiopod 5 (Fig. 6g): coxal plate anterolobate; posterior margin of basis almost straight, with about 7 short setules; merus, carpus, and propodus with strong spines, intermixed with a few setae which are shorter than or equal to length of spines.

Pereiopod 6 (Fig. 6h) > pereiopod 5; coxal plate anterolobate; posterior margin of basis slightly concave, with some 6 short setules and 1 subdistal spine; armature of long segments as in pereiopod 5 .

Pereiopod 7 (Fig. 6i) slightly shorter than pereiopod 6; coxal plate non-lobate; basis tapering, posterior margin almost straight, with 7 short setules and 1 subdistal spine; armature of long segments as in pereiopod 6.

Coxal gills stalked, ovate; large on gnathopod 2 and pereiopods 3 through 5 , smaller on pereiopod 6.

Uropod 1 (Fig. 7a) reduced, not reaching distal end of peduncle of uropod 2 (Fig. 5h); exopodite much shorter than endopodite; both rami devoid of dorsal armature; distal spine strong, but not very long, claw-like, accompanied by 2 setules; length endopodite (+ claw) equal to or slightly longer than length of peduncle.

Uropod 2 (Fig. 7b) normal: endopodite slightly longer than exopodite: dorsal margin of endopodite naked, that of exopodite with 1 dorsal spine; each ramus with 5 distal elements of which one much longer than the others.

Uropod 3 (Fig. 7c): exopodite 2-segmented; segment 1 ca. 5 times as long as largest diameter; lateral and medial margins with 4 groups of spines and some scarce setae which are usually shorter but sometimes longer than the spines; segment 2 small, with 4 distal setules; endopodite scale-like, with 2 distal spines.

Telson (Fig. 5i) cleft; each lobe subovate, with 1 or 2 lateral spines, 3 distal spines, and 2 or 3 distal setules which are shorter than the spines.

Female: As usual in gammarids, the female morphology offers hardly any good discriminating characters. The female of the present species is adequately described by Karaman (1991) under the name of $R h$. nivariae. In contrast to $R h$. nivariae, the propodus of pereiopod $3 q$ is devoid of a fan of filtrative setae. Ovigerous females carry few large eggs, usually 1 to 3 , sometimes up to 5 .

Juveniles: In young specimens the characteristic setal fan on pereiopod 3 is still lacking or poorly developed. Furthermore, juveniles have fewer setal groups on the peduncle of antennae 1 and 2, a lower number of flagellar segments, a lower number of C-setae on the mandible palp, a lower number of distal elements on the palp of maxilla 1, and a shorter third uropod.

Etymology. - The specific name is derived from the terra typica, the island of La Gomera.

Discussion. - The presence of a species of Rhipidogammarus on La Gomera was demonstrated recently by Karaman (1991). He had only one ovigerous female, from an unspecified locality, at his disposal, which he provisionally identified as $R h$. nivariae Stock, 1988, a subterranean taxon described from Tenerife. In 1990, a second species of Rhipidogammarus, $R h$. rheophilus, was described from Tenerife, living in freshwater surface streams (Stock \& Sánchez, 1990). The remaining four species of the genus [Rh. rhipidiophorus (Catta, 1870), $R h$. karamani Stock, 1971, Rh. variicauda Stock, 1978 , and $R h$. triumvir Notenboom, 1985] all are distributed around the borders of the western and central Mediterranean, the first two mainly in mixohaline waters, the last two in fresh subterranean waters. The six named taxa in this genus form a closely-knit cluster, distinguished by subtle differences only.

The rich material from La Gomera showed that the Rhipidogammarus from this island is neither identical with $R h$. nivariae, as supposed by Karaman, nor with any of the other described species. 
We therefore propose a new species for it, called Rh. gomeranus.

$R h$. gomeranus belongs to a small group of species with a high number (4 to 6 ) of setal groups on the ventral margin of peduncle segment 2 of antenna 1. This group comprises $R h$. triumvir, $R h$. nivariae, and $R h$. rheophilus.

In the male sex, $R h$. gomeranus differs from $R h$. triumvir ${ }^{1}$ in (1) the long setae (longer than the diameter of the segment) on peduncular segments 2 and 3 of antenna 1 (short in triumvir); (2) the number of palmar angle spines of gnathopod 1 (6 in gomeranus, vs. 5 in triumvir) and gnathopod 2 (5 vs. 4); (3) the length of the endopodite of uropod 1 (as long as the peduncle in gomeranus, 1.5 times as long in triumvir, cf. Fig. 7d) (there are also slight differences in uropod 2, compare Figs. 7b and 7e); (4) the setae on the ventral margin of peduncle segments 4 and 5 of antenna 2 (longer and arranged in a greater number of groups in gomeranus); (5) the ratio length carpus/length merus in pereiopod 7 (1.6 in gomeranus, 1.9 in triumvir).

The male sex of both $R h$. nivariae and $R h$. rheophilus differs from $R h$. gomeranus in (1) the chaetotaxis of the anterior margin of merus and carpus of pereiopod 7 (in gomeranus spines outnumber the setae, and both are of subequal length; in the two other species setae outnumber the spines, and the setae are longer); (2) similar, though slightly less pronounced, differences in chaetotaxis are present in pereiopods 5 and 6; (3) $R h$. gomeranus has 5 instead of 4 spine-teeth on the palp of the right maxilla 1, and 9 instead of 8 setae on the left palp; (4) the length of the ventral setae on peduncular segment 2 of antenna 1 exceeds the diameter of the segment in gomeranus, but equals the segment diameter in nivariae and rheophilus; (5) the number of C-setae on mandibular palp segment 3 is 7 to 8 in gomeranus, 3 to 5 in the two other species; (6) the setae on both margins of exopodite segment 1 of uropod 3 are numerous and twice as long as the spines in nivariae and rheophilus, scarce and as long as the spines in gomeranus.

\footnotetext{
1 The data on $R h$. triumvir used in this paper are based on Notenboom's original description (1985) and on re-examination of the type-material.
}

Ecology and distribution. - Up to now, this species was only found at medium altitudes $(790-980 \mathrm{~m}$ above sea level) in the north-west and south-west of La Gomera (Fig. 8), but not in the El Cedro system where Chaetogammarus was encountered. It occurs chiefly in water trickles on rock slopes, but also in spring brooks, as well as in a "levada" (artificial aquaduct) not far from a spring.

Two localities (Fuente Erque and a spring in Montaña de la Caldera) are outside and on the limit, respectively, of the Laurisilva zone; Las Mesetas is located in the Ocotea woods.

It should be stressed that the two other Canarian species of Rhipidogammarus, both from Tenerife, occur at much lower altitudes (between 3 and $210 \mathrm{~m}$ above sea level) than the new species.

\section{Biogeography of the freshwater gammaroids of La Gomera}

Four species of inland water amphipods are actually known from La Gomera: Melita dulcicola Stock \& Vonk, 1990, Pseudoniphargus gomerae Stock, 1988a, Rhipidogammarus gomeranus n. sp., and Chaetogammarus chaetocerus $\mathbf{n}$. sp.

The first, Melita dulcicola, is apparently a fairly recent descendant of a marine ancestor (Stock \& Vonk, 1990). The second, belonging to the genus Pseudoniphargus, prolific in taxa especially in the Iberian peninsula and on certain Atlantic islands (Canary Islands, Madeira, Azores, Bermuda), likewise is supposed to have had its origin from a marine, shallow-water ancestor, in the Tethys Sea at the end of the Mesozoic, when the Atlantic Ocean had not yet opened up and primordials of the islands were already available as shallow marine banks or fragments of the American and Eurafrican continental plates (Stock, 1993).

Rhipidogammarus is restricted to brackish and fresh waters in the western part of the Mediterranean area, from the northern belt of the Adriatic in the east to Spain in the west, but has in addition two species on Tenerife in the Canary Islands (Stock, 1988c; Stock \& Sánchez, 1990). The new species of Chaetogammarus recorded from La Gomera belongs to an exclusively limnic group of species of 


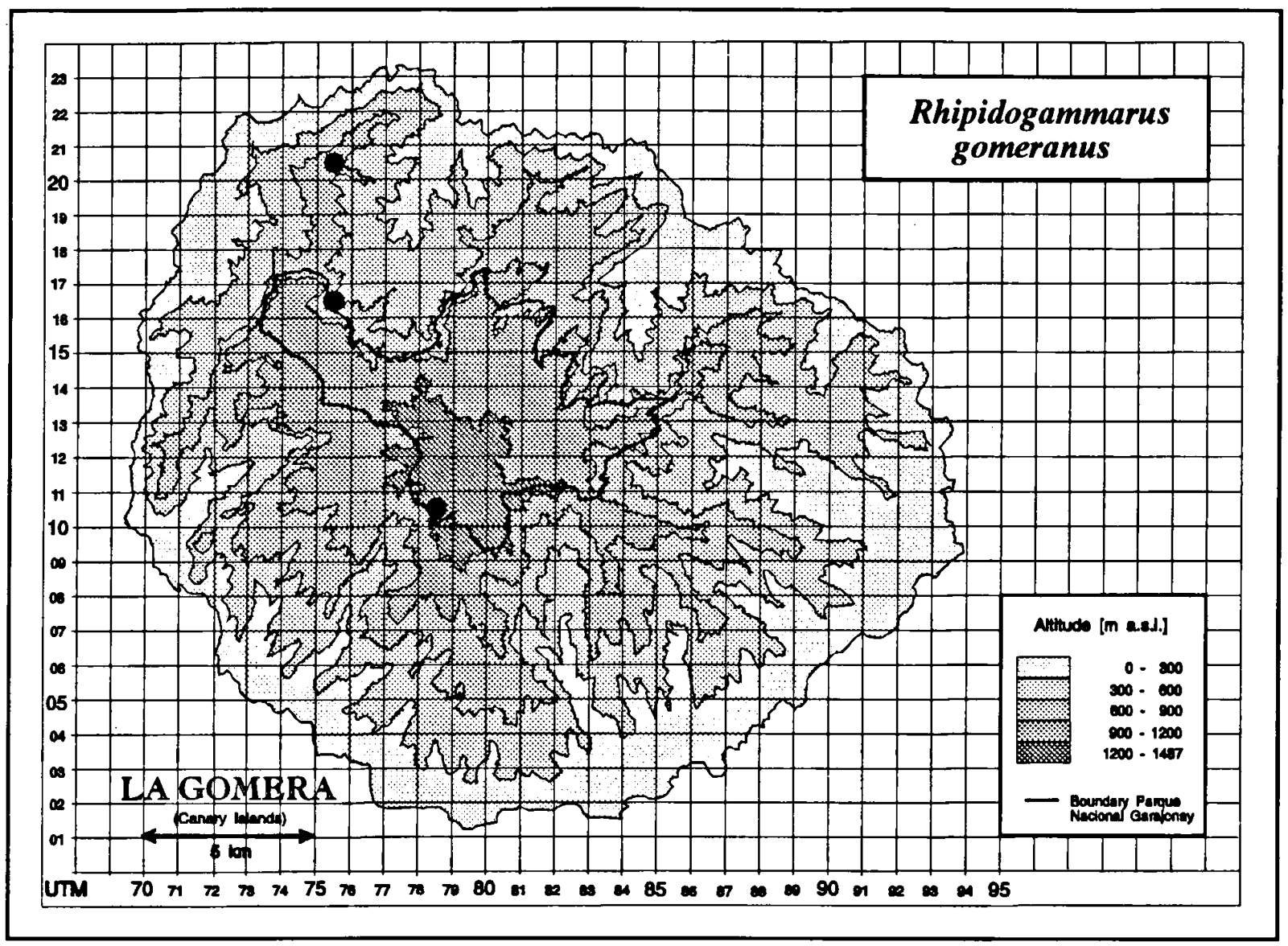

Fig. 8. Distribution of Rhipidogammarus gomeranus n. sp. in La Gomera (a.s.l. = above sea level).

the genus, known as the Chaetogammarus (or Echinogammarus) simoni-group. Members of this group are known from north and northwestern Africa and the Iberian peninsula.

Stock (1988c, 1990) postulates a closer contact between the Canary Islands and the Mediterranean Tethyan belt in the early Tertiary than is apparent from the present-day off-shore location of the islands of the Canary archipelago. Giraud (1985) considered it possible for the Canarian island of Fuerteventura that the surrection of a plutonic massif (the so-called Basal Complex) and the correlative folding of sediments took place during the late Senonian. The first emergence of the island can be placed in the late Cretaceous, with later regressive movements in the early Eocene, around the Eocene/Oligocene boundary, and in the Neogene (Giraud, as cited by Boutin, 1993: 230). Although many geologists suppose that La Gomera is geologically younger than Fuerteventura, it is the only other island of the Canary archipelago from which an extensive Basal Complex is known. In analogy, and concurring with the views of Boutin (1993: 238), we postulate that the radiation under limnic conditions of the ancestors of the Chaetogammarus simoni-groub. both in Africa and in the Canarias, started during the Senonian regressions. Also the records of species of Rhipidogammarus from La Gomera and Tenerife lend support to this idea.

Records of freshwater amphipods from other islands in the Canarias, in particular of Metacrangonyx (formerly Pygocrangonyx) in Fuerteventura give further support to the supposition of a closer shallow-water contact between these islands and the western Mediterranean/North African region (see 
Stock \& Rondé-Broekhuizen, 1986; Stock, 1988b; Boutin, 1993).

\section{Acknowledgements}

The fieldwork in La Gomera of the first author was financially supported by the Richard-Winter Stiftung, Bergisch Gladbach (Germany).

The Instituto Nacional para la Conservación de la Naturaleza (ICONA), La Gomera, is thanked for the permission to carry out studies in the Parque Nacional de Garajonay and for hospitality during the period of the fieldwork.

\section{References}

Barnard, J.L. \& C.M. Barnard, 1983. Freshwater Amphipoda of the world: $\mathrm{i}-\mathrm{vii}, \mathbf{1 - 8 3 0}$, in 2 vols. (Hayfield Associates, Mt. Vernon, Virginia).

Beyer, G., 1993. Limnologische und biogeografische Untersuchungen an Quellen und Bächen der Kanaren-Insel La Gomera. Diplomarbeit Math.-Naturwiss. Fakultät, Rheinische Friedrich-Wilhelms-Univ., Bonn: 1-182.

Boutin, C., 1993. Biogéographie historique des Crustacés Malacostracés stygobies du Maroc. Thèse de Doctorat, Univ. Claude Bernard - Lyon I, 843842L: 1-283.

Giraud, R., 1985. Tectonique post-hercynienne en Afrique du Nord et de l'Ouest. In: Evolution géologique de l'Afrique: 185-224 (C.I.F.E.G., Paris.)

Jaume, D., 1992. Troballa d'Echinogammarus sicilianus (Crustacea: Amphipoda) a les Serres de Llevant de Mallorca. Bolletí Societat Hist. nat. Balears, 34: 41-49.

Karaman, G.S., 1977. Revision of the Echinogammarus genera complex (fam. Gammaridae). Arhiv biol. Nauka, Beograd, 27 (1/2): 69-93.

Karaman, G.S., 1988. Two new species of the family Gammaridae from Tunisia and Madagascar. Poljoprivreda i Sumarstvo, 34 (1) “1987”': 17-38.

Karaman, G.S., 1991. Further discovery of genus Rhipidogammarus Stock (Gammaridea, Gammaridae) on Canary Islands
(Atlantic). Poljoprivreda i Sumarstvo, 37 (1/2): 17-33.

Notenboom, J., 1985. Rhipidogammarus triumvir n. sp. (Amphipoda, Gammaridae) from wells near Mojonera, Almería. Stygologia, 1 (3): 292-299.

Pinkster, S. \& D. Platvoet, 1990. Some remarks on the genus Echinogammarus Stebbing, 1899 with description of a new species E. valedictus from Algeria (Crustacea, Amphipoda). Bijdr. Dierk., 60 (3/4): 263-269.

Pinkster, S. \& J.H. Stock 1972. Members of the Echinogammarus simoni-group and the genus Eulimnogammarus (Crustacea - Amphipoda) from the Iberian peninsula and North Africa, with description of a new species. Bull. zoöl. Mus. Univ. Amsterdam, 2 (10): 85-115.

Stock, J.H., 1988a. The amphipod genus Pseudoniphargus (Crustacea) in the Canary Islands. Bijdr. Dierk., 58 (1): 477.

Stock, J.H., 1988b. A new Rhipidogammarus (Crustacea, Amphipoda) from Tenerife: first record of the genus outside the Mediterranean and its biogeographic implications. Hydrobiologia, 169: 279-292.

Stock, J.H., 1988c. Amphipoda (Crustacea) from inland groundwaters of Fuerteventura. Bull. zoöl. Mus. Univ. Amsterdam, 11 (12): 105-113.

Stock, J.H., 1990. Insular groundwater biotas in the (sub)tropical Atlantic: a biogeographic synthesis. Atti Convegni Lincei, Accad. naz. Lincei Roma, 85: 695-713.

Stock, J.H., 1993. Some remarkable distribution patterns in stygobiont Amphipoda. J. nat. Hist., 27: 807-819.

Stock, J.H., in press. Gammarus and Chaetogammarus (Crustacea, Amphipoda) from Macaronesia. Bolm. Mus. mun. Funchal, 45.

Stock, J.H. \& B.L.M. Rondé-Broekhuizen, 1986. A new species of Pygocrangonyx, an amphipod genus with African affinities, from Fuerteventura. Bijdr. Dierk., 56 (2): 247-266.

Stock, J.H. \& E.Sánchez, 1990. First record of Crustacea Malacostraca from fresh waters in the Canary Islands. Hydrobiologia, 206: 53-59.

Stock, J.H. \& R. Vonk, 1990. A freshwater amphipod from La Gomera. Melita dulcicola n. sp. Annls. Limnol., 26 (1): 29-37.

Received: 28 July 1993

Revised: 23 November 1993 